\title{
The significance of erythropoietin and insulin administration on survival of fat tissue after autologous fat transplantation in Wistar rats. An experimental study
}

\author{
IUlia Olaru ${ }^{1)}$, Anca Sava ${ }^{2,3)}$, Camelia Tamaş ${ }^{4,5)}$, CLAudia Florida Costea ${ }^{6,7)}$, \\ GABRIELA FLORENTA DUMITRESCU ${ }^{3)}$, AURELIAN SORIN PAŞCA ${ }^{8}$, FLORIN ŞTEFAN OLARU ${ }^{1)}$, \\ TEODOR STAMATE ${ }^{4,5)}$ \\ 1) Department of Plastic Surgery and Reconstructive Microsurgery, Sf. Apostol Andrei Emergency Clinical Hospital, Galaţi,
Romania \\ 2) Department of Morpho-Functional Sciences I, Grigore T. Popa University of Medicine and Pharmacy, Iaşi, Romania \\ 3) Laboratory of Pathology, Prof. Dr. Nicolae Oblu Emergency Clinical Hospital, Iaşi, Romania \\ 4) Department of Surgery I, Grigore T. Popa University of Medicine and Pharmacy, Iaşi, Romania \\ 5) Department of Plastic Surgery and Reconstructive Microsurgery, Sf. Spiridon Emergency Clinical Hospital, Iaşi, Romania \\ 6) Department of Surgery II, Grigore T. Popa University of Medicine and Pharmacy, Iaşi, Romania \\ 7) $2^{\text {nd }}$ Ophthalmology Clinic, Prof. Dr. Nicolae Oblu Emergency Clinical Hospital, Iaşi, Romania \\ 8) Department of Pathology, Ion Ionescu de la Brad University of Agricultural Sciences and Veterinary Medicine, Iaşi, \\ Romania
}

\begin{abstract}
Autologous fat transfer is widely used by plastic surgeons for aesthetic and reconstructive purpose, but it has a great disadvantage because of its high variability rate of resorption. Numerous studies have examined the use of different agents to increase the viability of fat grafts. The results were discouraging because the use of a single angiogenic factor to stimulate fat graft angiogenesis may be inappropriate. We proposed to use two pharmacological factors, erythropoietin (EPO) and insulin (INS), in order to decrease the resorption rate, to improve graft vascularization, and to reduce the number of complications. Twenty-four Wistar male rats were randomly divided in four groups (I-IV) of six animals each. The rats belonging to control group were given autologous transfer of simple fat. In group II, the graft was improved with EPO, in group III with INS, and in group IV both pharmacological agents were administered. Histological evaluation of the grafts at two months after injection demonstrated adipocyte survival in all four groups. The volume of the graft has progressively decreased in all groups and the difference in graft volume at one and two months after transplantation was not significant. The highest maintenance of fat graft volume $(95 \%)$ at two months was observed in group IV, followed by group II and group III. Necrotic cystic changes and increased fibrosis were most extensive in the control group. The combination of INS with EPO may have a synergistic and additive effect. Efficient administration and dose optimization of these growth factors are important things to consider in the future.
\end{abstract}

Keywords: fat transplantation, lipofilling, free fat grafts, insulin, erythropoietin.

\section{口 Introduction}

Autologous fat transplantation (AFT) is widely used by plastic surgeons in post-traumatic reconstructions and for cosmetic purpose to reduce the effects of aging, but the scientific understanding of this procedure has been exceeded by clinical use. Although there have been numerous in vitro and in vivo experimental studies, as well as clinical studies in human subjects, the lack of understanding was probably due to the high variability rate of resorption of the transplanted fat grafts.

AFT was initially described by Neuber, in 1893 [1], and in 1911 Bruning was the first one who injected autologous fat into subcutaneous cellular tissue to correct the aesthetic outcome of a rhinoplasty [2]. Over the next 40 years, this procedure has not been widely used. In 1950, the subject was reassessed by Peer, who noted that fat grafts retain only $50 \%$ of their weight and volume [3].
The evolution of fat grafting can be influenced by some factors, such as the choice of the donor site, the presence of good vascularization at the receptor site, the amount of fat injected, the method of fat harvesting and processing, some hormones, and drugs.

Current studies suggest that early and adequate vascularization of free fat grafts is essential for its integration and viability [4]. The unpredictable resorptions rate of transplanted tissue reduces the efficacity of this technique because the volume of non-vascularized graft continues to decrease because of increased cell death after transplantation.

Using individually angiogenic factors [5] or vascular endothelial growth factor (VEGF) therapy to stimulate angiogenesis in order to increase the survival and viability of fat grafts [6,7], different authors obtained discouraging results, because the use of a single angiogenetic factor to stimulate angiogenesis may be insufficient.

This is an open-access article distributed under the terms of a Creative Commons Attribution-NonCommercial-ShareAlike 4.0 International Public License, which permits unrestricted use, adaptation, distribution and reproduction in any medium, non-commercially, provided the new creations are licensed under identical terms as the original work and the original work is properly cited. 
In the light of these findings, the aim of our research was to experimentally investigate the effects on fat graft of two pharmacological factors: erythropoietin (EPO) and insulin (INS) that was administrated into Wistar rats in order to establish if there are any stimulation of angiogenic factors releasing, if any angiogenesis is promoted, thus preventing adipocyte apoptosis, and if any differentiation of adipose stem cell, especially in adipogenic lines, could appear.

\section{Materials and Methods}

The study was conducted on 24 Wistar male rats from the Cantacuzino National Institute of Research and Development for Microbiology and Immunology, Bucharest, Romania, weighing 380 to $460 \mathrm{~g}$, with the age of at least 52 weeks.

The experimental design was fully approved by the Research Ethics Committee of Grigore T. Popa Medicine and Pharmacy University, Iaşi, Romania.

\section{Pre-harvesting steps}

The pre-experiment acclimatization of the mice was assured by hosting them in constant temperature $\left(24 \pm 0.7^{\circ} \mathrm{C}\right)$ and humidity $(60 \pm 10 \%)$ conditions, and the circadian cycle (light/darkness) was established to 12 hours each. All rats had a standard diet and water ad libitum.

The rats were randomly divided into four groups of six animals each. The dorsal aspect of the rats was chosen as the recipient site, minimizing the chance of endogenous fat contamination, due to the absence of the fat between subcutaneous tissue and underlying muscle in this area. At the end of the study, harvesting the graft was easier following this procedure.

The rats belonging to group I, considered to be the control group, were given autologous transplantation of simple fat. In group II, the graft was improved with EPO, in group III with INS, and in group IV both pharmacological agents were administered.

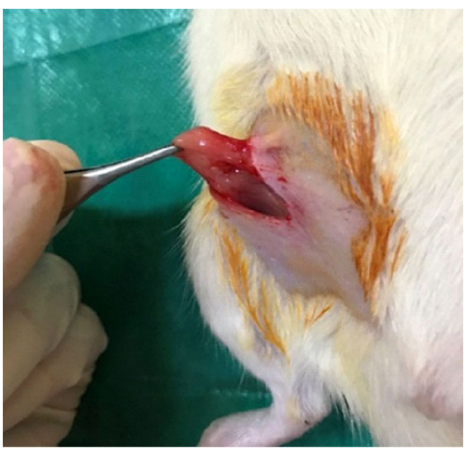

Figure 1 - Harvesting the autologous fat for transplantation from

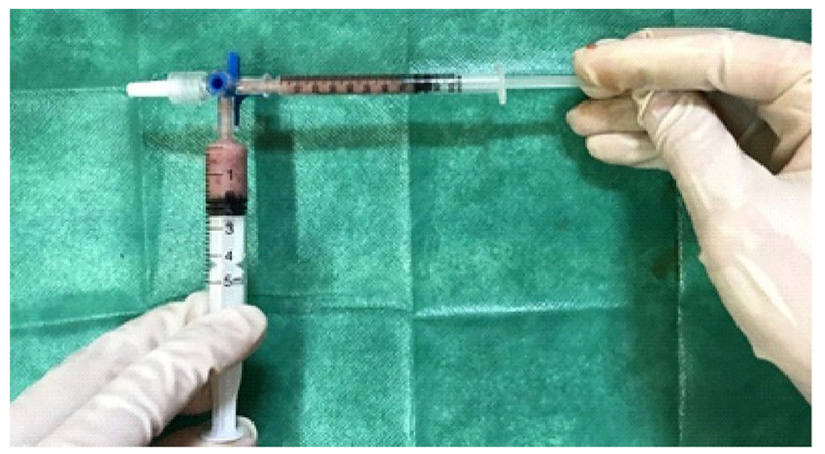

Figure 2 - Transferring the adipose tissue into the injection syringe.
All rats were operated under general anesthesia using $2 \%$ Xylazine for sedation $-0.1 \mu \mathrm{g} / 100 \mathrm{~g}$ animal, and after 10-15 minutes Ketamine $1 \mathrm{mg} / \mathrm{mL}-0.1 \mu \mathrm{g} / 100 \mathrm{~g}$ animal. Substances were intraperitoneally injected.

The surgical procedure was performed under sterile conditions, respecting the general rules of asepsis and antisepsis.

\section{Harvesting the adipose tissue}

Autologous fat tissue was obtained from the right groin area of the rat. The ipsilateral dorsal plan and the inguinal area were mechanically shaved and prepared with Povidone-Iodine.

Oblique incisions, about $3 \mathrm{~cm}$ in length, were performed for harvesting the grafts. Inguinal fat was exposed making the dissection with a Stevens scissors, and the fat graft was harvested (Figure 1). The donor area was washed with antibiotic solution (saline and Rifampicin) and closed with separate 5/0 monofilament nonabsorbable suture.

\section{Preparing the fat graft}

The adipose tissue obtained from each rat was cut into small pieces using a Stevens scissors and then placed into a $5 \mathrm{~mL}$ syringe and washed with saline (1/3 proportion) three times to remove debris and blood.

After that, we left the fat graft to decant, in the same syringe used for washing, approximately 10 minutes. The content separated in three layers: inferior - a pink layer with blood and debris, the middle layer - containing adipose tissue, and the superior layer - with mostly oil. The inferior layer was discarded, and aliquots of $1 \mathrm{~mL}$ of the middle layer were transferred to $1 \mathrm{~mL}$ syringes, to avoid additional fat graft contact with the air and to reduce the risk of oxidative cytolysis (Figure 2).

\section{Injection}

The injection was performed using a $16 \mathrm{G}$ cannula by punching the ipsilateral dorsal plane of the rats (Figure 3).
Group I of rats were injected with $1 \mathrm{~mL}$ autologous fat without any treatment (control group). Group II of rats were injected with $1 \mathrm{~mL}$ fat that was mixed with $5000 \mathrm{IU} / \mathrm{kg}$ EPO. EPO was purchased as a prefilled syringe Binocrit ${ }^{\circledR}$ (Sandoz, Austria) with $40000 \mathrm{IU} / \mathrm{mL}$. In group III, the fat was mixed with $10 \mu \mathrm{L}$ INS Lantus ${ }^{\circledR}$ (Sanofi-Aventis, Germany) $100 \mathrm{U} / \mathrm{mL}$, and in the group IV was used both pharmacological factors in the same concentration.

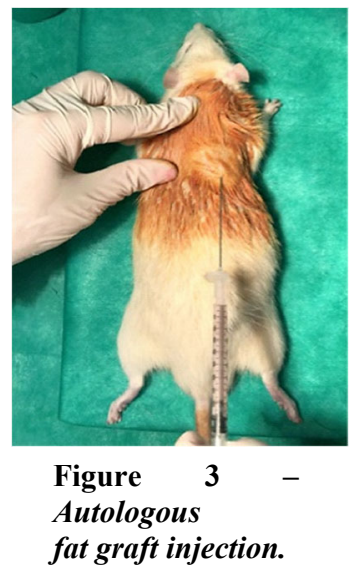

Post-operative antibiotics, analgesics or other drugs were not administrated to the rats in all four groups, over the two months study period, during which animals were checked daily for clinical signs of infection, fat rejection or behavior problems.

\section{Harvesting the fat grafts}

All rats survived until the end of the study. Fat graft removal was performed at two weeks, one month and 
two months, by euthanizing two rats from each group. The fat graft remained as a subcutaneous lump and was removed by taking a rectangular cutaneous flap, approximately $3 / 2 \mathrm{~cm}$ in size with a lateral pedicle in the dorsal plane of the rat (Figure 4, A and B).
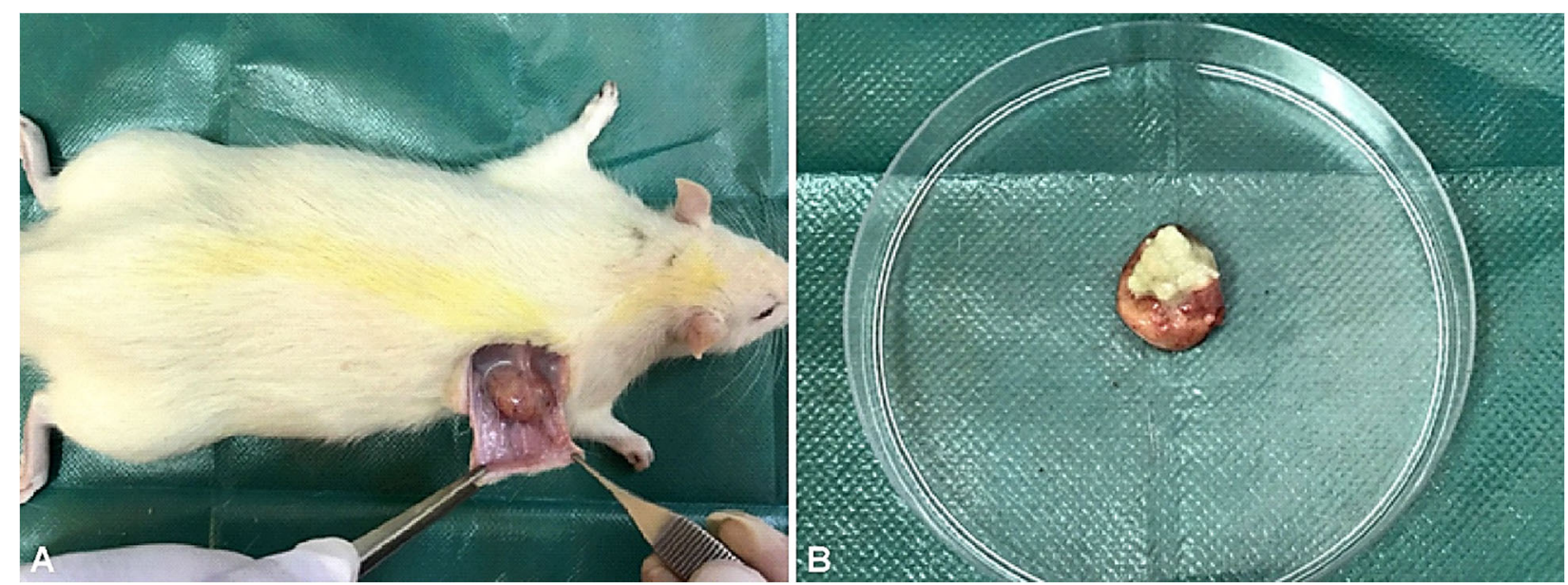

Figure 4 - The macroscopic aspect of fat graft at 14 days after injection, group IV: (A) The fat graft as a subcutaneous lump; (B) The fat graft was a nodule with a thin capsule and yellow adipose tissue-like content.

\section{Histological and immunohistochemical analysis}

Immediately after harvesting, tissue fragments were fixed in 10\% neutral buffered formalin solution for 48 hours, processed by the paraffin inclusion method (Leica TP 1020 processor, Germany) and sectioned (RM 2235 microtome, Leica, Germany) to a thickness of $5 \mu \mathrm{m}$. The sections were stained with Hematoxylin-Eosin (HE) and Goldner-Szekely (GS) trichrome. Immunohistochemistry was performed using mouse monoclonal anti-cluster of differentiation 68 (CD68) (Dako, Denmark), anti-Vim (vimentin) (1:100 dilution, Dako, Denmark), and anti-cytokeratin (CK) AE1/AE3 (1:350 dilution, Bio SB) antibodies. For examination, we used a photonic microscope (Leica DM 1000, Germany), a digital histological camera (Leica $5 \mathrm{mpx}$, full HD, Germany) and LAS software, 2019 version.

The evaluated histological parameters were: $(i)$ intact adipocytes; (ii) new blood vessel formation (angiogenesis); (iii) degree of inflammation represented by lymphocyte and macrophage infiltration; (iv) fibrosis extension represented by collagen fibbers formation; $(v)$ the presence of cysts, and vacuoles; and ( $v i$ ) calcifications. Each parameter was evaluated using a quantitative scale ranging from 0 to 5 (0 - absent, 1 - minimal, 2 - minimal to moderate, 3 moderate, 4 - moderate to extensive, 5 - extensive). All histological parameters were blindly evaluated.

\section{Statistical analysis}

In order to analyze the data, the nonparametric KruskalWallis test was used due to reduced number of subjects. A $90 \%$ significance level was accounted for also due to reduced number of subjects and Mann-Whitney $U$-test for median differences was used to establish significance of differences between each group and the direction of each difference.

\section{Results}

\section{Gross findings}

The macroscopic analysis reveals that fat grafts have maintained their yellow color, also at two months. There was no gross evidence of acute inflammation, necrosis, seroma collection or abscess formation in all four groups.

At 14 days postoperatively, the presence of a conjunctive capsule surrounding the fat graft was observed. It separated the graft from the adjacent tissues, facilitating the dissection (Figure 4, A and B). New blood vessels were also identified 14 days after injection.

At one month postoperatively, the graft lost its compact appearance, gaining an irregular shape, and the surrounding capsule was less represented. At two months, the graft retained the appearance of one month.

The volume of the graft was measured using the liquid overflow method. The graft was introduced into a syringe filled with saline and the increase in fluid level was recorded as the volume of the graft.

Initially, the volume of the grafts increased over the first 14 days due to oedema formation. The volume has progressively decreased in all groups but the difference in volume at one and two months was not significant. We can conclude that marked graft resorption occurred in the first month (Figure 5).

In group IV was observed the highest maintenance of fat graft volume at two months $(95 \%)$, followed by group II (85\%) and group III (75\%), with the worst results in group I $(35 \%)$.

\section{Histological analysis}

Neovascularization vessels and adipocyte viability followed the same trend as volume maintenance. Necrotic cystic changes were most extensive in control group, followed by groups II and III. The fibrosis was observed mainly increased in group I, moderate in groups II and III, and reduced in group IV (Table 1).

In the control group, at two weeks, we notice large territories with inflammatory infiltrate (mononuclear/ neutrophils, macrophages), microthrombosis and ischemic area of necrosis. The number of viable adipocytes was quite small (Figure 6, A-C). During two months of evolution, the graft was replaced with cysts (post-necrosis of adipose tissue) and thick bands of connective tissue (Figure 7, A 
and B). In the scar connective tissue, could be observed agglomeration of macrophages, whose cytoplasm has intense immunopositivity for the anti-CD68 antibody. A low degree of angiogenesis was observed. The surviving adipocytes were identified only in the periphery of the graft.

On the other hand, in group IV, where the adipose tissue was improved with INS and EPO, at two weeks there was reduced inflammatory infiltrate, associated with reduced necrosis areas, and reduced peripheral fibrosis. At one month, the stroma was well formed and had numerous capillaries of neoformation, but not significant morphological changes of adipocytes were observed. At two months, the adipose tissue contains uniform adipocytes, separated by a delicate conjunctive stroma, with numerous blood capillaries of neoformation. Adipocytes were well represented even in the central area (Figure 8, A and B); inflammatory infiltrate was absent and an abundance of neoformation blood capillaries was observed. The necrosis was decreased.

Table 1 - Results of the Kruskal-Wallis test

\begin{tabular}{|c|c|c|c|c|c|c|}
\hline Group & $\begin{array}{c}\text { Adipocytes } \\
H(3)=12.26 \\
p=0.007\end{array}$ & $\begin{array}{c}\text { Angiogenesis } \\
H(3)=13.91 \\
p=0.003\end{array}$ & $\begin{array}{c}\text { Inflammation } \\
H(3)=10.88 \\
p=0.012\end{array}$ & $\begin{array}{c}\text { Fibrosis } \\
H(3)=16.12 \\
p<0.001\end{array}$ & $\begin{array}{c}\text { Cysts/vacuoles } \\
H(3)=15.86 \\
p<0.001\end{array}$ & $\begin{array}{c}\text { Calcifications } \\
\begin{array}{c}H(3)=13.34 \\
p=0.004\end{array}\end{array}$ \\
\hline $\mathrm{I}$ & 5.25 & 5.83 & 19.08 & 21.42 & 20.67 & 21.50 \\
\hline II & 14.92 & 16.67 & 8.50 & 9.08 & 10.33 & 10.50 \\
\hline III & 12.17 & 9.50 & 14.67 & 10.42 & 8.67 & 9 \\
\hline IV & 17.67 & 18.30 & 7.75 & 5.05 & 4.33 & 9 \\
\hline
\end{tabular}

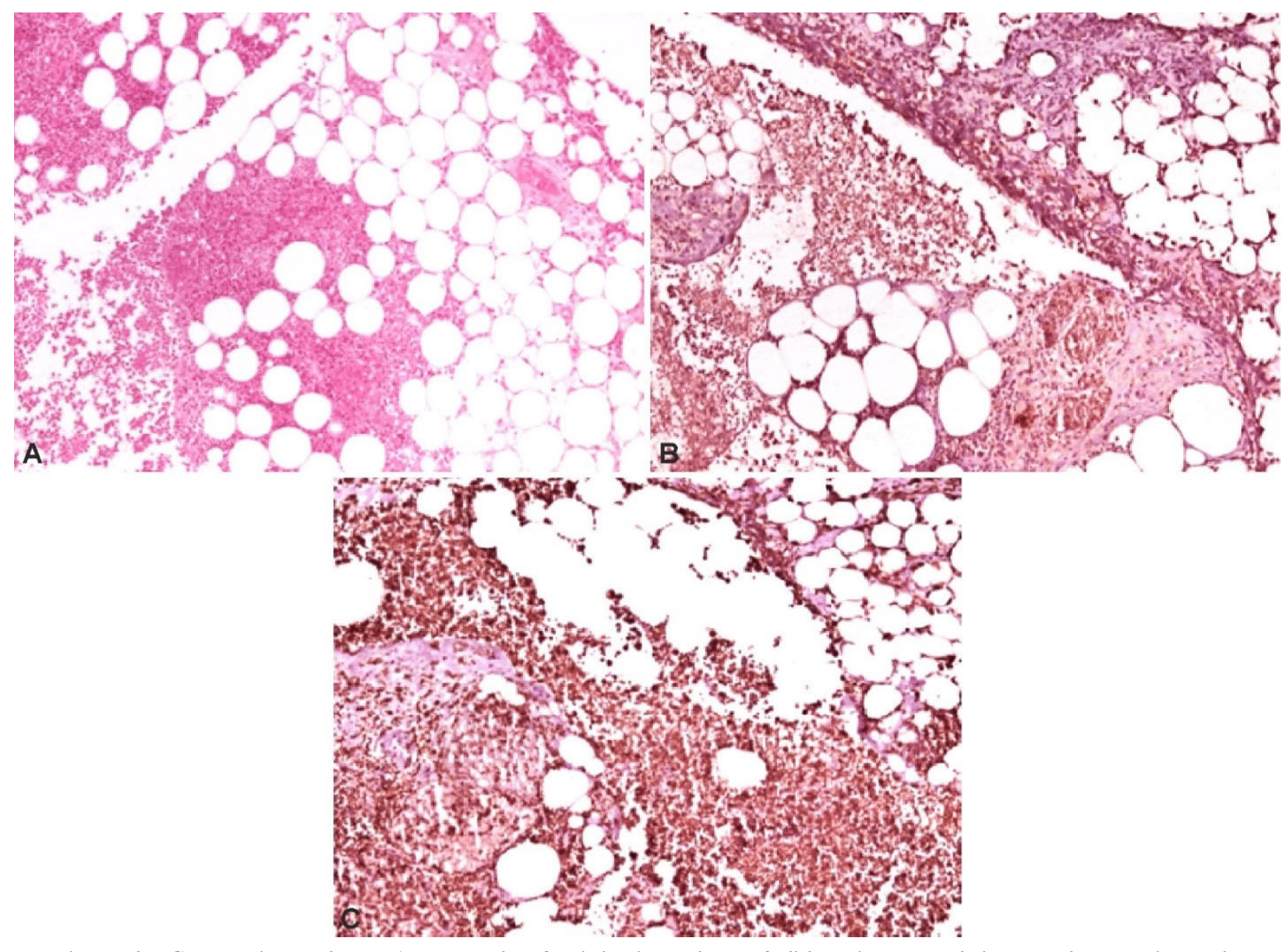

Figure 6 - Group I (control group), two weeks after injection. The graft did not integrate, being mostly necrotic. In the central area, there are also several necrotic glandular structures that also confirm the non-integration of the graft: (A) HE staining, ×100; (B) IHC, anti-CK AE1/AE3 antibody, $\times 100$; (C) IHC, anti-Vim antibody, $\times 100$. CK: Cytokeratin; HE: Hematoxylin-Eosin; IHC: Immunohistochemistry; Vim: Vimentin. 


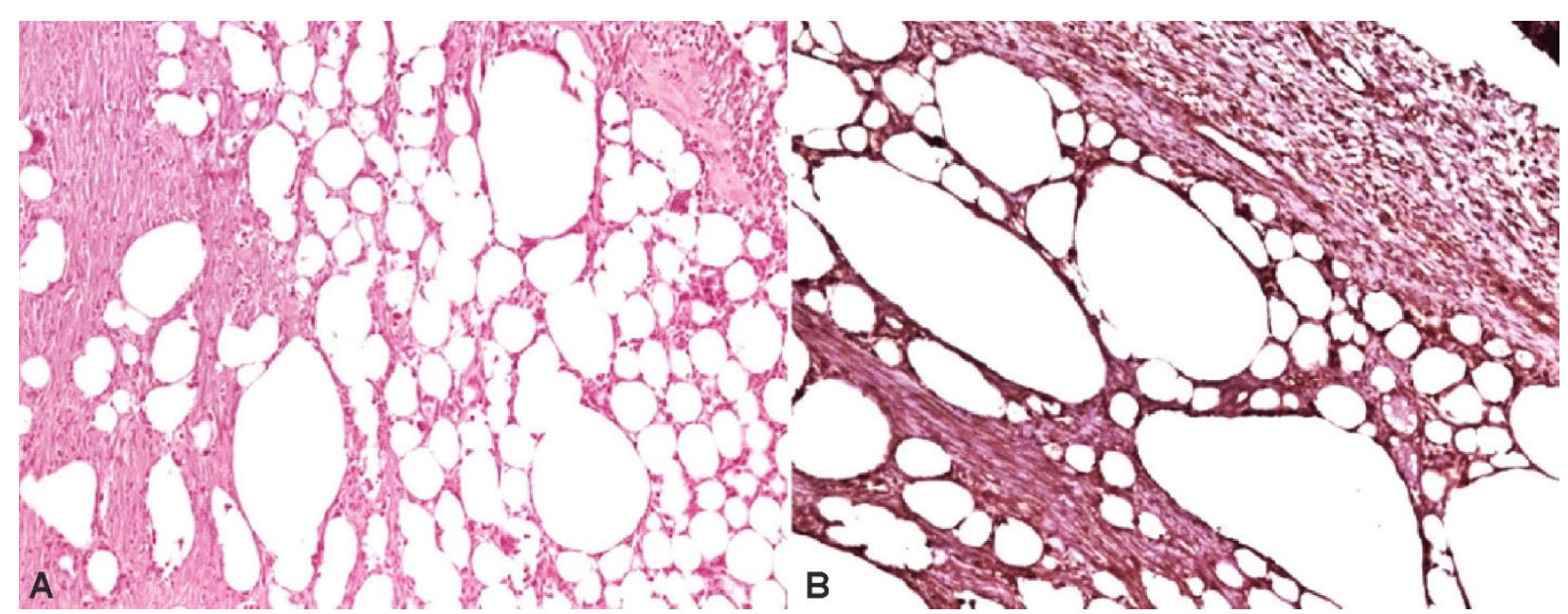

Figure 7 - Group I (control group), one month after injection. The adipose tissue graft did not integrate: (A) In the central area, there are large numerous cyst that replaced the necrotized adipocytes (HE staining, $\times 100)$; (B) Dense connective tissue and large cysts have been replaced the necrotized adipocytes (IHC, anti-Vim antibody, $\times 100)$. HE: Hematoxylin-Eosin; IHC: Immunohistochemistry; Vim: Vimentin.

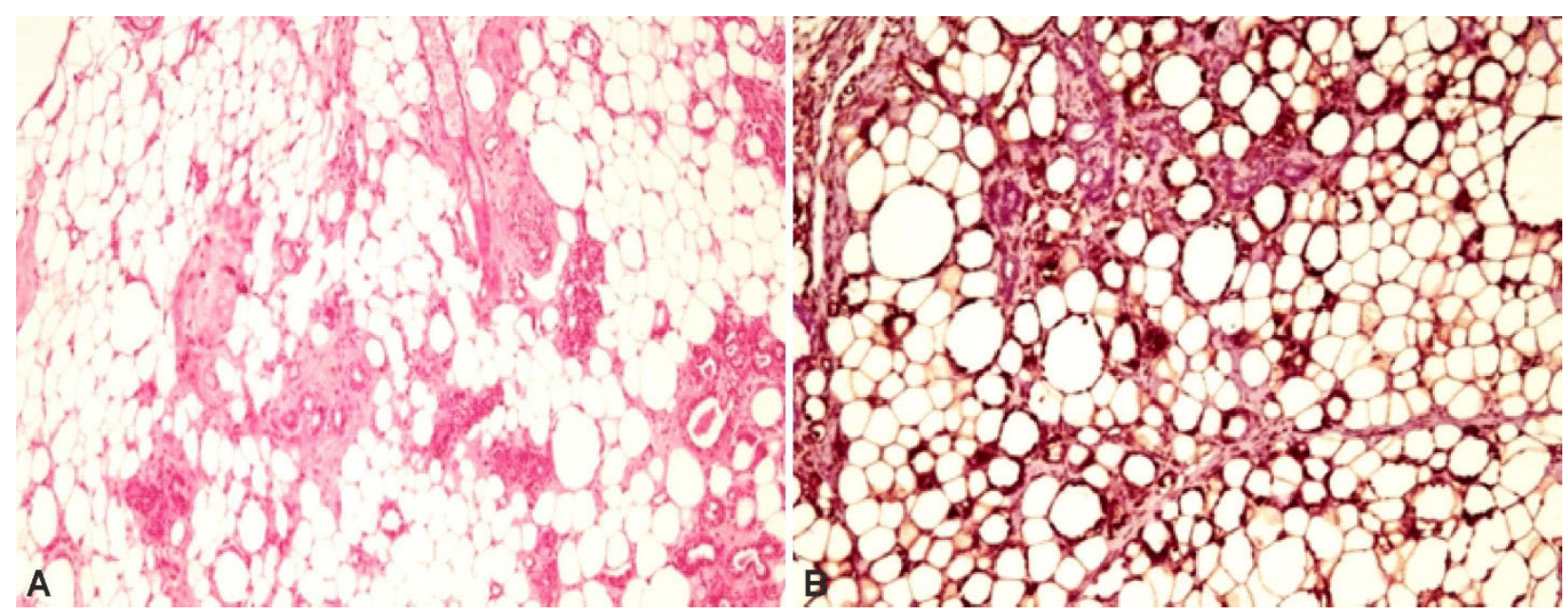

Figure 8 - Group IV, two months after injection. Viable adipose tissue with blood vessels, epithelial glandular structures, and reduced inflammatory infiltrate: (A) HE staining, $\times 100$; (B) IHC, anti-Vim antibody, $\times 100 . \mathrm{HE}$ : HematoxylinEosin; IHC: Immunohistochemistry; Vim: Vimentin.

Statistical analyzes of groups II and III, using MannWhitney $U$-test, did not reveal any significant differences for most of the histopathological (HP) parameters, except new blood formation and inflammation, while difference regarding intact adipocytes, fibrosis extension, the presence of cysts, and calcifications, were not significantly different (Table 2).

In group II, at two weeks after fat transplantation, a moderate neutrophilic leukocyte infiltrate can be observed in the interstitial tissue with moderate degeneration of adipocytes. At two months after fat transplantation, the inflammatory process was reduced, and newly formed blood vessels, mature adipocytes and interstitial conjunctive hyperplasia were observed (Figure 9, A-D). In group III, at two months after fat transplantation, we observed welldeveloped angiogenesis, represented by numerous small and medium-sized blood vessels; normal adipocytes predominated, and well-formed conjunctive stroma could be seen (Figure 10, A-C).

In some grafts, we also observed non-uniform adipocytes, including large adipocytes, overloaded with lipids, in contact with new-formed blood vessels. In both groups (II and III), we identified a relatively good graft integration, but there were also hypercellular scar-type connective tissue, as well as cysts.

Table 2 - Results of the Mann-Whitney U-test

\begin{tabular}{cccccccc}
\hline Group & Parameters & Adipocytes & Angiogenesis & Inflammation & Fibrosis & Cysts/vacuoles & Calcifications \\
\hline \multirow{5}{*}{ I vs. II } & $U$ & 3.50 & 2 & 2.50 & 1.30 & 2 & 1.22 \\
\cline { 2 - 8 } & $z$ & -2.43 & -2.71 & -2.54 & -3.01 & -2.66 & 3.05 \\
\cline { 2 - 8 } & $p$ & 0.01 & 0.003 & 0.01 & 0.003 & 0.008 & 0.002 \\
\cline { 2 - 8 } & Median I & 2 & 2 & 4.5 & 3.5 & 2 & 3 \\
\cline { 2 - 8 } & Median II & 4 & 3 & 2 & 1 & 0.001 & 1 \\
\hline \hline
\end{tabular}


Iulia Olaru et al.

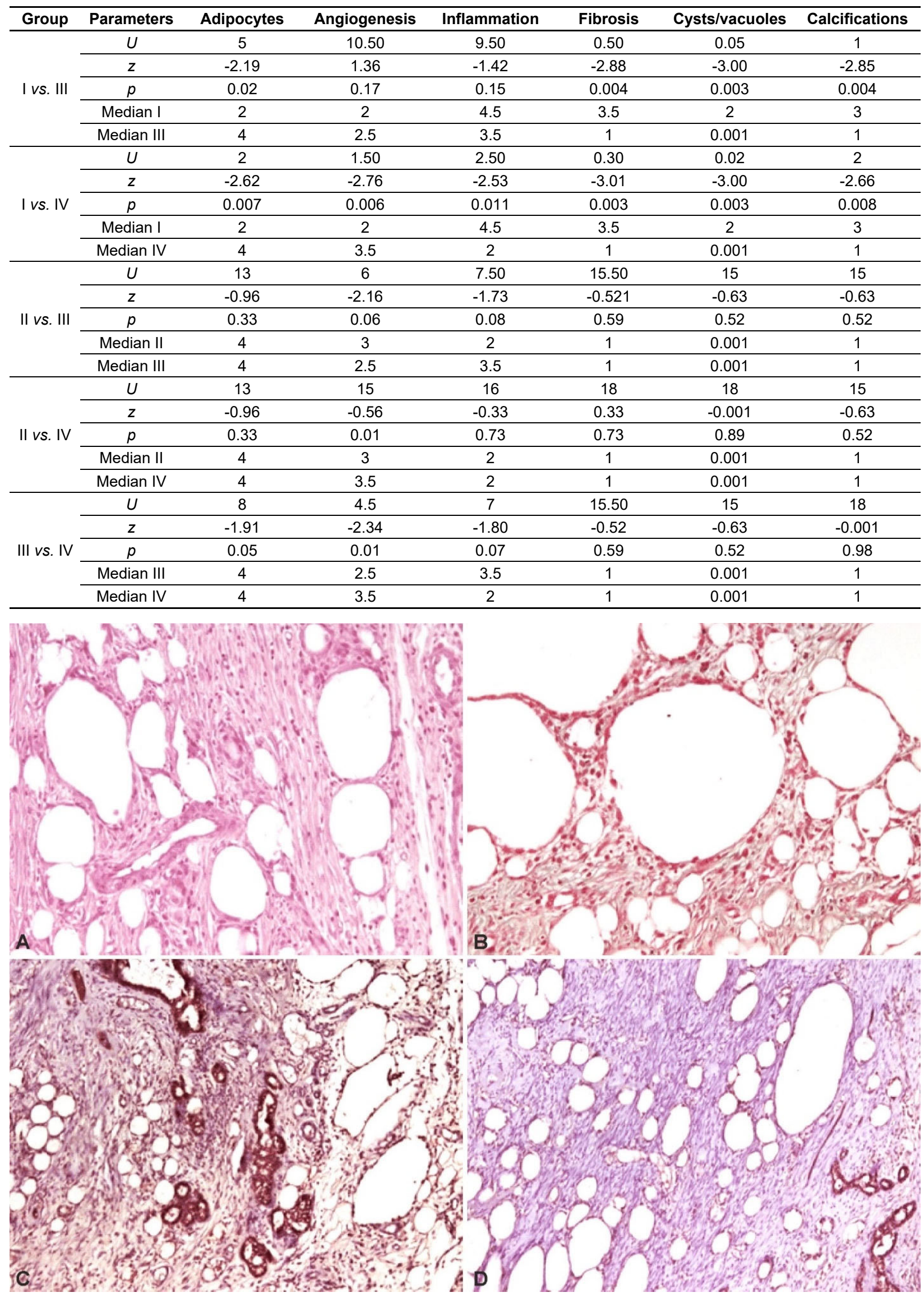

Figure 9 - Group II, two months after injection. Relatively poor integration of the graft, with the presence of scarce viable adipose tissue, arranged in small lobules separated by thick conjunctive septa. Cyst with different shapes and dimensions were embedded into the dense conjunctive tissue, along with some distorted glands: (A) HE staining, $\times 100$;

(B) GS trichrome, $\times 200$; (C) IHC, anti-CK AE1/AE3, ×100; (D) IHC, anti-Vim antibody, $\times 200$. CK: Cytokeratin; GS: Goldner-Szekely; HE: Hematoxylin-Eosin; IHC: Immunohistochemistry; Vim: Vimentin. 


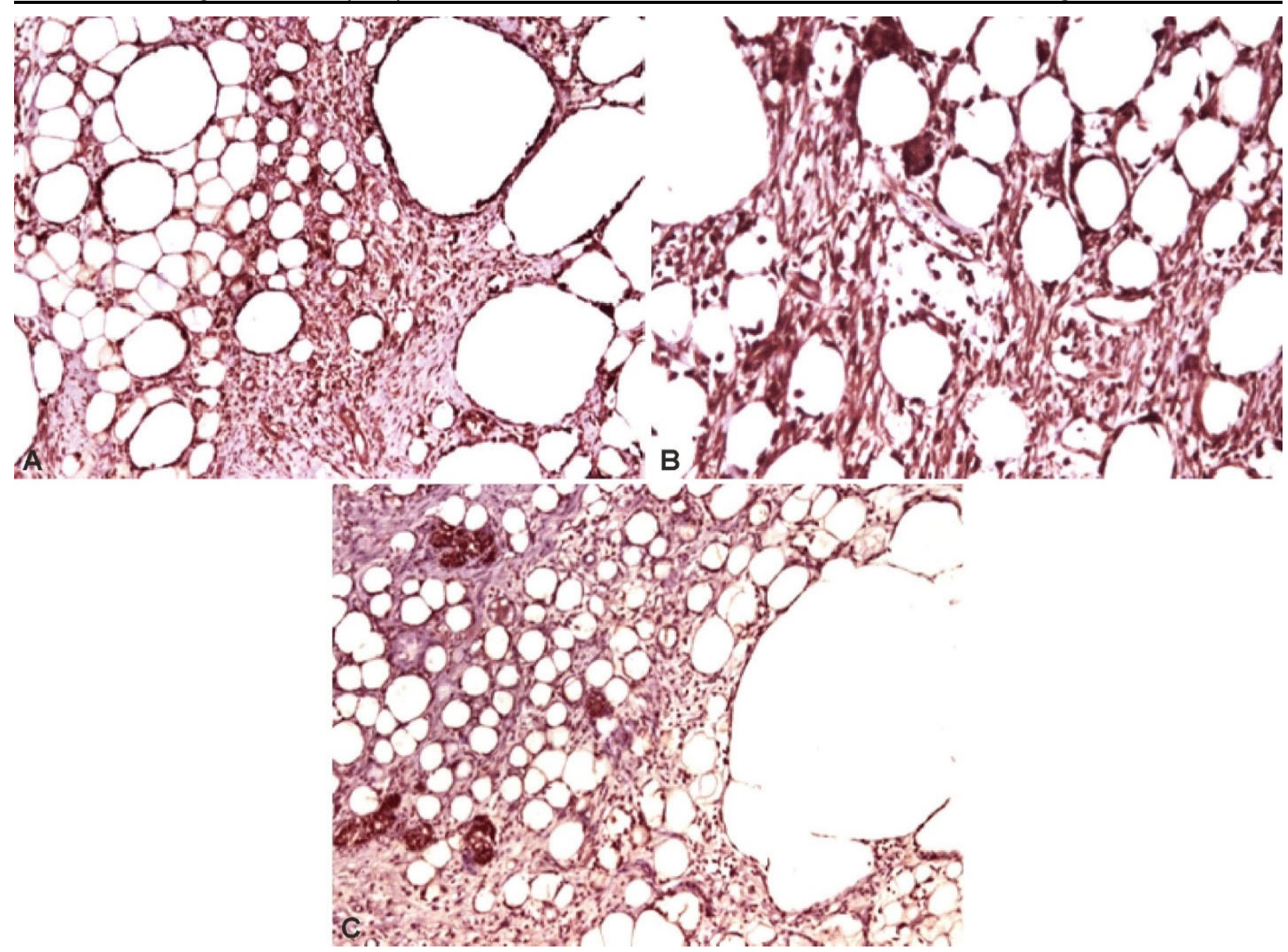

Figure 10 - Group III, two months after injection. Relatively good integration of the graft, with the presence of viable adipose tissue, arranged in lobules separated by conjunctive septa, along with some cysts with different shapes and dimensions and rare glandular structures: (A) IHC, anti-Vim antibody, $\times 100$; (B) IHC, anti-Vim antibody, $\times 200$; (C) IHC, anti-CK AE1/AE3, ×100. CK: Cytokeratin; IHC: Immunohistochemistry; Vim: Vimentin.

\section{Discussions}

The ideal filler for soft tissue augmentation should be easy to obtain, non-carcinogenic, non-teratogenic, non-inflammatory and non-migratory and with a good cost-efficiency ratio $[8,9]$. It must also have predictable and persistent results and have minimal or no risk of transmitting infectious diseases.

Autologous adipose tissue is abundant, soft, versatile, with a minimal morbidity of the donor site. Because it is an autologous implant, antigenic and allergenic reactions are not met [10].

The satisfactory results are observed in the immediate postoperative period, while sometimes, the long-term results are disappointing for both surgeon and patient $[11,12]$. To compensate the high resorption rate was tried overcorrection (injection of a larger volume than necessary) and repeated lipofilling sessions [13, 14].

Unfortunately, overcorrection can cause serious problems, such as central necrosis of the graft, which may require surgical removal in some cases. Also, repeated lipofilling procedures increase the risk of infection being associated with impaired vascularization at the receptor site and increased resorption rate [15]. It has been shown that long-term efficiency of the procedure depends on neovascularization of grafts by anastomosing with host vascularization and maintaining the receptor site uninfected $[16,17]$.
The lack of consensus and standardization of this procedure with unpredictable resorption results limits many plastic surgeons to use it [18]. The technical procedures of harvesting and grafting have been investigated to optimize the surgical protocol, but the methods of preparing the fat before the injection remain controversial [19].

Some authors have observed that INS injection into transplanted tissue will cause adipocyte hypertrophy because INS induces acetyl-CoA carboxylase, increasing adipose tissue synthesis [20].

Several methods have also been used to increase the viability of transplanted adipose tissue: the use of interleukin-8 [21], selective beta-blockers [22], fibroblast growth factor [23], hyperbaric oxygen therapy [24]. However, no simple method capable of effectively increase the viability of fat grafts, that is widely applied in clinical cases, has been published.

It has been reported that INS can stimulate primary cell lines of cultured adipocytes to proliferate and differentiate into mature adipocytes in vitro [20].

There is a large number of inflammatory cells present in the lipoaspirate, thus suggesting the potential of the fat mass to produce an inflammatory response. In a recent study was observed that inflammatory cytokines mediate the integration and survival of adipose cells [25]. The interaction between vascularization and inflammatory cytokines may be crucial for the survival and functionality of transplanted adipocytes. 
EPO, a glycoprotein hormone, is involved in enhancing the immune response by exerting anti-inflammatory effects and in the induction of angiogenesis by instigating the secretion of angiogenic factors [26].

Sabbatini et al. [27] noted the provascular properties of the EPO. In particular, they showed that EPO induces an increases number of cluster of differentiation 31 (CD31)-positive microvessels. In addition, EPO has a direct effect on leukocyte tissues infiltration. Reducing the number of macrophages is an important thing that can highlight a reduced inflammatory status. It also stimulates angiogenesis indirectly in ischemic tissue by increasing expression of the VEGF and by recruiting progenitor endothelial cells [28].

Hamed et al. reported that the effects of EPO on the survival of transplanted adipose tissue are better than those of VEGF [29]. EPO administration has benefits both locally and systemically, this being demonstrated by injecting subcutaneous EPO in hemodialysis patients [30].

In an animal study, it was observed that continuous EPO administration using an osmotic pump improves recovery from total cerebral ischemia [31]. Kim et al. observed that continuous EPO administration in nude mice, does not have benefits on the survival of transplanted adipose tissue, but improves the HP profile of the graft [26].

Early revascularization of fat grafts is very important for the viability of transplanted adipose tissue. Angiogenic factors including VEGF begin revascularization of fat grafts seven days after transplantation. Fat grafts are sensitive to ischemia during this period and delayed vascularization is critical for adipocytes. As a result, morphological changes of adipocytes are observed, the adipocyte cell membrane is detached, and adipocyte cysts and vacuoles develop in areas where no revascularization has occurred [2]. Thus, fat grafts are gradually resorbed after cell destruction [4]. Fibrotic tissue development is also common, but never fully compensates for the volume of lost adipocytes [2]. Moreover, the clinical applicability of angiogenic factors, such as INS and EPO, have been shown to contribute to fat graft viability.

\section{ㅁ Conclusions}

Recent studies have focused on drugs or biological factors capable of improving the long-term fat graft integration and survival. EPO and INS appear to have promising results. They have the big advantage to be already approved drugs and that the effects of their administration on humans are known. It is already demonstrated that INS and EPO administration have a trophic effect on vascularization, an anti-inflammatory role and leads to an improvement in adipocyte survival and proliferation. In this experiment, the pathological findings reveal the synergistic and additive effect of INS with EPO combination in AFT method. Efficient administration and dose optimization for these growth stimulating factors are important things to consider in the future. Several studies with different doses, and the observation of the long-term stimulatory effect are needed before clinical applicability is considered.
Conflict of interests

The authors do not declare any conflict of interests.

\section{References}

[1] Neuber G. Über die Wiederanheilung vollständig vom Körper getrennter, die ganze Fettschicht enthaltender Hautstücke. Zbl f Chirurgie, 1893, 30:16-17.

[2] Sommer B, Sattler G. Current concepts of fat graft survival: histology of aspirated adipose tissue and review of the literature. Dermatol Surg, 2000, 26(12):1159-1166. PMID: 11134994

[3] Peer LA. Cell survival theory versus replacement theory. Plast Reconstr Surg (1946), 1955, 16(3):161-168. https://doi.org/ 10.1097/00006534-195509000-00001 PMID: 13266544

[4] Yamaguchi M, Matsumoto F, Bujo H, Shibasaki M, Takahashi K, Yoshimoto S, Ichinose M, Saito Y. Revascularization determines volume retention and gene expression by fat grafts in mice. Exp Biol Med (Maywood), 2005, 230(10):742-748. https:// doi.org/10.1177/153537020523001007 PMID: 16246901

[5] Rophael JA, Craft RO, Palmer JA, Hussey AJ, Thomas GP, Morrison WA, Penington AJ, Mitchell GM. Angiogenic growth factor synergism in a murine tissue engineering model of angiogenesis and adipogenesis. Am J Pathol, 2007, 171(6): 2048-2057. https://doi.org/10.2353/ajpath.2007.070066 PMID: 18055559 PMCID: PMC2111127

[6] Yi CG, Xia W, Zhang LX, Zhen Y, Shu MG, Han Y, Guo SZ. VEGF gene therapy for the survival of transplanted fat tissue in nude mice. J Plast Reconstr Aesthet Surg, 2007, 60(3): 272-278. https://doi.org/10.1016/j.bjps.2006.01.052 PMID: 17293285

[7] Lu F, Li J, Gao J, Ogawa R, Ou C, Yang B, Fu B. Improvement of the survival of human autologous fat transplantation by using VEGF-transfected adipose-derived stem cells. Plast Reconstr Surg, 2009, 124(5):1437-1446. https://doi.org/10. 1097/PRS.0b013e3181babbb6 PMID: 20009828

[8] Derder M, Whitaker IS, Boudana D, Marchac A, Hivelin M, Mattar N, Lepage C, Claude O, Benjoar MD, Bosc R, Lantieri $L$. The use of lipofilling to treat congenital hypoplastic breast anomalies: preliminary experiences. Ann Plast Surg, 2014, 73(4):371-377. https://doi.org/10.1097/SAP.0b013e3 1827fb3b7 PMID: 23759965

[9] Coleman SR, Saboeiro AP. Fat grafting to the breast revisited: safety and efficacy. Plast Reconstr Surg, 2007, 119(3):775785; discussion 786-787. https://doi.org/10.1097/01.prs.00 00252001.59162.c9 PMID: 17312477

[10] Bucky LP, Kanchwala SK. The role of autologous fat and alternative fillers in the aging face. Plast Reconstr Surg, 2007, 120 (6 Suppl):89S-97S. https://doi.org/10.1097/01.prs.0000 248866.57638.40 PMID: 18090347

[11] Ross RJ, Shayan R, Mutimer KL, Ashton MW. Autologous fat grafting: current state of the art and critical review. Ann Plast Surg, 2014, 73(3):352-357. https://doi.org/10.1097/SAP. Ob013e31827aeb51 PMID: 23788141

[12] Davis GB, Lang JE, Peric M, Yang H, Artenstein D, Chan LS, Schooler WG, Carey JN. Breast reconstruction satisfaction rates at a large county hospital. Ann Plast Surg, 2014, 72(Suppl 1):S61-S65. https://doi.org/10.1097/SAP.000000 000000171 PMID: 24691306

[13] Carpaneda CA, Ribeiro MT. Study of the histologic alterations and viability of the adipose graft in humans. Aesthetic Plast Surg, 1993, 17(1):43-47. https://doi.org/10.1007/BF00455048 PMID: 8430529

[14] Niechajev I, Sevćuk O. Long-term results of fat transplantation: clinical and histologic studies. Plast Reconstr Surg, 1994, 94(3):496-506. https://doi.org/10.1097/00006534-19940900 0-00012 PMID: 8047602

[15] Bayram Y, Sezgic M, Karakol P, Bozkurt M, Filinte GT. The use of autologous fat grafts in breast surgery: a literature review. Arch Plast Surg, 2019, 46(6):498-510. https://doi.org/ 10.5999/aps.2019.00416 PMID: 31775202 PMCID: PMC 6882697

[16] Yoshimura K, Sato K, Aoi N, Kurita M, Hirohi T, Harii K. Cell-assisted lipotransfer for cosmetic breast augmentation: supportive use of adipose-derived stem/stromal cells. Aesthetic Plast Surg, 2008, 32(1):48-55; discussion 56-57. https:// doi.org/10.1007/s00266-007-9019-4 PMID: 17763894 PMCID: PMC2175019 
[17] Moseley TA, Zhu M, Hedrick MH. Adipose-derived stem and progenitor cells as fillers in plastic and reconstructive surgery. Plast Reconstr Surg, 2006, 118(3 Suppl):121S-128S. https://doi.org/10.1097/01.prs.0000234609.74811.2e PMID: 16936551

[18] Del Vecchio D, Rohrich RJ. A classification of clinical fat grafting: different problems, different solutions. Plast Reconstr Surg, 2012, 130(3):511-522. https://doi.org/10.1097/PRS.0 b013e31825dbf8a PMID: 22929236

[19] Strong AL, Cederna PS, Rubin JP, Coleman SR, Levi B. The current state of fat grafting: a review of harvesting, processing, and injection techniques. Plast Reconstr Surg 2015, 136(4):897-912. https://doi.org/10.1097/PRS.000000 0000001590 PMID: 26086386 PMCID: PMC4833505

[20] Yuksel E, Weinfeld AB, Cleek R, Wamsley S, Jensen J, Boutros S, Waugh JM, Shenaq SM, Spira M. Increased free fat-graft survival with the long-term, local delivery of insulin, insulin-like growth factor-I, and basic fibroblast growth factor by PLGA/PEG microspheres. Plast Reconstr Surg, 2000 105(5):1712-1720. https://doi.org/10.1097/00006534-20000 4050-00017 PMID: 10809102

[21] Shoshani O, Livne E, Armoni M, Shupak A, Berger J, Ramon Y, Fodor L, Gilhar A, Peled IJ, Ullmann Y. The effect of interleukin-8 on the viability of injected adipose tissue in nude mice. Plast Reconstr Surg, 2005, 115(3):853-859. https://doi.org/ 10.1097/01.prs.0000153036.71928.30 PMID: 15731687

[22] Ayhan M, Senen D, Adanali G, Görgü M, Erdoğan B Albayrak B. Use of beta blockers for increasing survival of free fat grafts. Aesthetic Plast Surg, 2001, 25(5):338-342. https://doi.org/10.1007/s002660010145 PMID: 11692246

[23] Eppley BL, Sidner RA, Platis JM, Sadove AM. Bioactivation of free-fat transfers: a potential new approach to improving graft survival. Plast Reconstr Surg, 1992, 90(6):1022-1030. https://doi.org/10.1097/00006534-199212000-00013 PMID: 1280367

[24] Shoshani O, Shupak A, Ullmann Y, Ramon Y, Gilhar A, Kehat I, Peled IJ. The effect of hyperbaric oxygenation on the viability of human fat injected into nude mice. Plast Reconstr Surg, 2000, 106(6):1390-1396; discussion 1397-1398. https:// doi.org/10.1097/00006534-200011000-00028 PMID: 11083573
[25] Goldstein DR. Inflammation and transplantation tolerance. Semin Immunopathol, 2011, 33(2):111-115. https://doi.org/ 10.1007/s00281-011-0251-2 PMID: 21331502

[26] Kim EK, Lee Y, Lee HJ, Hong JP. Local subcutaneous injection of erythropoietin might improve fat graft survival, whereas continuous infusion using an osmotic pump device was harmful by provoking an overwhelming foreign body reaction in a nude mouse model. Arch Aesthetic Plast Surg, 2018, 24(3):128133. https://doi.org/10.14730/aaps.2018.24.3.128

[27] Sabbatini M, Bosetti M, Borrone A, Moalem L, Taveggia A Verna G, Cannas M. Erythropoietin stimulation of human adipose tissue for therapeutic refilling releases protective cytokines. J Tissue Eng, 2016, 7:2041731416671278. https:// doi.org/10.1177/2041731416671278 PMID: 27738510 PMCID: PMC5042341

[28] Sabbatini M, Moalem L, Bosetti M, Borrone A, Boldorini R, Taveggia A, Verna G, Cannas M. Effects of erythropoietin on adipose tissue: a possible strategy in refilling. Plast Reconstr Surg Glob Open, 2015, 3(3):e338. https://doi.org/10.1097/ GOX.0000000000000305 PMID: 26034645 PMCID: PMC 4448713

[29] Hamed S, Egozi D, Kruchevsky D, Teot L, Gilhar A, Ullmann Y. Erythropoietin improves the survival of fat tissue after its transplantation in nude mice. PLoS One, 2010, 5(11):e13986. https://doi.org/10.1371/journal.pone.0013986 PMID: 21085572 PMCID: PMC2981551

[30] Wright DG, Wright EC, Narva AS, Noguchi CT, Eggers PW. Association of erythropoietin dose and route of administration with clinical outcomes for patients on hemodialysis in the United States. Clin J Am Soc Nephrol, 2015, 10(10):18221830. https://doi.org/10.2215/CJN.01590215 PMID: 26358266 PMCID: PMC4594062

[31] Undén J, Sjölund C, Länsberg JK, Wieloch T, Ruscher K, Romner B. Post-ischemic continuous infusion of erythropoietin enhances recovery of lost memory function after global cerebral ischemia in the rat. BMC Neurosci, 2013, 14:27. https://doi.org/10.1186/1471-2202-14-27 PMID: 23497299 PMCID: PMC3608158

\section{Corresponding authors}

Anca Sava, Professor, MD, PhD, Department of Morpho-Functional Sciences I, Faculty of Medicine, Grigore T. Popa University of Medicine and Pharmacy, 16 University Street, 700115 laşi, Romania; Phone +40744-303 678, e-mail: dr.anca.sava.68@gmail.com

Camelia Tamaş, Lecturer, MD, PhD, Department of Surgery I, Faculty of Medicine, Grigore T. Popa University of Medicine and Pharmacy, 16 University Street, 700115 laşi, Romania; Phone +40744-128 457, e-mail: camelia6ta@yahoo.com 